\title{
Place of Accounting in Providing Economic Safety to the Enterprises (Company)
}

\section{Steve Rahim*}

General Manager, Fairfield Inn, Edison, NJ, USA

In a market economy different forms of ownership develops, the independence of enterprises (companies) expands, new economic phenomena appears, and specific market conditions of managing. Independently from the form of ownership and type of activity, all economic entities intend to get more revenue and profits. However, in conditions of the market economy, increases the level of danger of doing business enterprises (companies). This is due to the following circumstances:

- The process of privatization creates an opportunity for to further develop independence of economic entities.

- Types and activities of enterprises (companies) are determined.

- Independently.

- Foreign economic activity of business entities develops, increasing the volume of exports and imports of goods.

- Foreign investment activity of enterprises (firms) are widely attracted.

- Business entities are to operate in accordance with international requirements (standards).

- The principle of self-sufficiency and self-financing becomes dominant, the main.

- Criterion for assessing the activity of the enterprise (company).

All these factors affect the maintenance of economic security of businesses. Overcoming or reducing the level of risk in the current economic conditions is becoming very urgent problem.

The results showed that the question of the economic emergence of danger, reducing the negative impact of risks on the enterprise (company) studied enough, in turn, these issues in the literature are not properly reflected.

Ensuring economic security depends on the following factors:

- A scientific approach to such categories as "economic risk of the enterprise" "economic risk", "economic security of the business entity" and others.

- Unjustified acceptance and risk classification companies.

- Organization of the risk management system.

- Reasonable organization of the system of control and accounting of business entities, allowing them economic security.

The economic security of the company depends largely on the presence of various risks. The risk, as an economic category, is a manifestation of certain phenomena associated with the external and internal factors, terms and conditions of the company. The literature shows the different types of risks. These include the following:*

- External risk,

- Internal risk,
- Economic risk,

- Financial risk,

- Production risk,

- Entrepreneurial risk,

- Risk of detection,

- Undetected risk,

- Other types of risks.

The activities of economic entities related to various risks. This is due to the fact that the production conditions on the facilities directly connected influenced by various factors.

${ }^{\star}$ For example: Business Economics (company): Textbook. Underred. prof. O.I.Volkova and Assoc. O.V. Devyatkina. - M: INFRA [1], both positive and negative.

Important in this timely aware of these factors, the consequences of their impact. As a result of the negative impact on the ongoing events in enterprises (companies), risks lead to losses, damages, negative financial results. Conversely, when a correct assessment, risk management, has an impact on its negative consequences it brings benefits, that is positive results. Therefore, a scientific approach to the risks justified their classification, help to reduce or limit the negative effects. This in turn provides economic security of companies (enterprises). According to the study we grouped the risks by the following features (Table 1):

Reducing the negative impact of risks contributes to economic security. In turn, all the phenomena which occur in activities of the economic entity, are recorded, summarized and controlled. Such a function in the company performs accounting. All economic phenomena are reflected in the account in the process of committing, through solid and continuous monitoring and recording. Then, based on the intermediate accounting registers compiled a generalized statements, which serves as the basis for a reliable assessment of the economic entity. Only by this information you can evaluate the various events that have had a positive or negative impact on the company. This fact leads us to conclude that accounting as a source of information and

\begin{tabular}{|c|c|c|}
\hline On the basis of appearance & External risk & internal risk \\
\hline Coverage activities of the subject & Economic risk & Financial risk \\
\hline For risk management purpose & Controllable risk & Uncontrollable risk \\
\hline
\end{tabular}

Table 1: Classification of risks of business entities.

*Corresponding author: Steve Rahim, General Manager, Fairfield Inn, Edison NJ, USA, Tel: 801-889-6036; E-mail: stevenr5072@hotmail.com

Received June 30, 2016; Accepted July 13, 2016; Published July 20, 2016

Citation: Rahim S (2016) Place of Accounting in Providing Economic Safety to the Enterprises (Company). J Account Mark 5: 185. doi:10.4172/2168-9601.1000185

Copyright: (c) 2016 Rahim S. This is an open-access article distributed under the terms of the Creative Commons Attribution License, which permits unrestricted use, distribution, and reproduction in any medium, provided the original author and source are credited. 
method of control is an important component of economic security of enterprises (companies) of various forms of ownership.

In a state of market economy, the content and function of accounting fundamentally changed. The flexibility of doing business, the presence of various risks, the need for their objective assessment and prevention, limiting the adverse effects of these risks, improving the competitiveness of business entities pose new challenges for the accounting, the impact of which contributes to economic security of enterprises (companies).

Market conditions determine new facilities management accounting and accounting policies as a whole. In the context of the introduction of innovative technologies and competitiveness, in our opinion accounting objects should expand due to the phenomena that will help reduce the negative effects of the economic dangers of businesses. The accounting policies have to find the forms and methods that directly affect the prevention, proper assessment, limit the danger of these subjects.

It should be noted that in the literature, in our opinion, did not find proper attention such issues as the danger, ensuring economic security, the role of accounting in the process. In the current economic conditions necessary to permit the following issues, related to ensuring the economic security of business entities:

- Scientific justification of such categories as "economic danger", "economic security" enterprise (company),

- Definition of a system of indicators that characterize the hazard and safety of a business entity,

- Development of methods of accounting of those phenomena that provide the restriction economic safety of enterprise (company),

- Definition of methods and techniques of accounting are intended to reflect the effects resulting from the economic danger and safety of businesses.

Preventing adverse effects of economic activities of enterprises should be one of the important tasks of accounting. The findings suggest that for important objects of accounting to ensure safety of should include the following: accounting effects, characterizing the hazard or safety of the enterprise, the organization subject to the contractual conditions between economic entities, records of income and expenses related to their individual types, according to the policies and tactics to reduce risks, including insurance protection enterprise, registration of foreign investment in purchasing power of customers. Preservation of trade secret account information is also an important condition for ensuring economic safety of the business entity (company). The results of the studies have come to certain conclusions and developed the following recommendations aimed at enhancing the role of accounting in providing economic safety of enterprises (companies):

- Scientifically justified concepts such as "economic danger enterprise", "economic safety", "assessment and limiting the economic dangers of the enterprise";

- Develop a system of indicators characterizing the economic threat and safety of businesses;

- To develop a method of accounting indicators characterizing the risk of economic and safety of entities;

- To recommend a standard form "accounting policy" of economic agents, which reflects the accounting methods and techniques that prevent the emergence of an economic threat;

Recommend a system of accounts to facilitate economic safety of businesses.

\section{References}

1. Volkova OI, Devyatkina OV (2002) Business economics (society). (3rdedn) INFRA-M. 